\title{
Accounting
}

\section{Determinants of financing decisions: Evidence using GMM estimation}

\author{
Thu-Trang Thi Doan ${ }^{\mathrm{a}^{*}}$
}

\begin{tabular}{l}
$\frac{{ }^{a} \text { Faculty of Finance and Banking, Indu }}{\text { C H R O N I C L E }}$ \\
\hline Article history: \\
Received May 102020 \\
Received in revised format May \\
152020 \\
Accepted June 262020 \\
Available online \\
June 26 2020 \\
\hline Keywords: \\
Capital structure \\
Manufacturing firms \\
Panel data \\
GMM estimation \\
Vietnam \\
\hline
\end{tabular}

\section{Introduction}

The financial decisions can be understood as decisions about the use of the firm's financial sources, which mainly focuse on the decision to use the loans (Cui et al., 2011). This is one of the important decisions of the firm (Sutomo et al., 2019). Not only that, the financial decisions are also a topic of study that is of great interest in empirical studies. Because, the financial decision changes the capital structure of the firm, thus significantly affecting the firm value (Modigliani \& Miller, 1958). If the financial decision is not appropriate, it can put the firms facing high risk of financial risk, even the risk of bankruptcy. Although the firms clearly recognize the importance of financial decisions, they still face the difficulties in making appropriate financial decisions. In order to address these difficulties, it is important to identify the determinants of firm's financial decisions. Based on this basis, the managers in the firms will have a basis to make reasonable financial decisions. However, the identification of determinants of financial decisions still has conflicting views. Not only that, these studies focus mainly on the developed economies, and there is a lack of empirical studies in emerging economies. Therefore, with this study article, the author will focus on answering the question "What factors will influence the firm's financial decision?". To answer this question, the author will conduct data collection of manufacturing firms in Vietnam, this is an emerging economy (Bui, 2019a, 2019b, 2020a). Therefore, this result promises to bring many interesting and important things for the firm managers.

\footnotetext{
* Corresponding author.

E-mail address: doanthithutrang@iuh.edu.vn (T.-T. T. Doan) 


\section{Literature review and study hypothesis}

The financial decision mainly focuses on the decision to use loans of the firms (Cui et al., 2011). Therefore, the financial decisions are usually measured through the ratio of total liabilities divided by total assets. This measurement was also found by the author in most previous studies. The determinants of financial decisions found by the authors in previous studies include profitability, liquidity, tangibility, and firm growth, and firm size.

\subsection{Impacts of profitability on a financing decision}

When the profit of the firm increases, the firm can take advantage of retained earnings to reinvest, thus reducing the amount of capital that needs to be mobilized from the outside through debt financing. Thereby, the firm will be more active in raising its capital, while limiting the increased financial risks due to loans. Therefore, increased profits can make the financial decisions lower. This impact was also found in most previous studies, such as Shah and Jam-e-Kausar (2012), Chechet et al. (2013), Chang et al. (2014), Wahab and Ramli (2014), Acaravci (2015), Windayu (2016), Vuran et al. (2017), Cevheroglu-Acar (2018), Li and Islam (2019), Ha (2019) and Sutomo et al. (2019). However, Moosa and Li (2012), Aggarwal and Singh (2014) argue that profitability can positively impact the financial decisions. Accordingly, when borrowing, the firms will gain many benefits from the tax shield, which has stimulated the firms to increase the liabilities instead of using retained earnings. Although there are some views that profits can have a positive impact on the financial decisions. However, most previous studies have suggested that the financial decisions are negatively impacted by the profits. In the emerging economies, raising capital through the form of liabilities is not always easy, and often takes more time than the decision to retain profits. Therefore, the firms still prioritize raising capital through retained earnings. Therefore, the author makes the following hypothesis:

\section{$H_{1}$ : Profitability or return on assets (ROA) negatively affects financing decision (FD).}

\subsection{Impacts of liquidity on financing decision}

The liquidity shows the ability that the firms can pay short-term liabilities. Therefore, the liquidity is usually measured through the ratio of short-term assets divided by short-term liabilities. Most previous studies have suggested that liquidity negatively affects the financial decisions, such as: Moosa and Li (2012), Wahab and Ramli (2014), Cevheroglu-Acar (2018). Accordingly, when the liquidity increases, the firms can be proactive in paying short-term liabilities. And also, the amount of working capital in the firms is also increasing, which may make these firms restrict their use of liabilities. However, there are also a few studies that have found positive impacts of liquidity on the financial decisions, such as Pahuja and Sahi (2015). Based on the results found in most previous studies, the author proposes the following hypothesis:

\section{$\mathrm{H}_{2}$ : Liquidity (LIQ) negatively affects financing decision (FD).}

\subsection{Impact of tangibility on financing decisions}

As tangible fixed assets increase, the firms tend to increase the liabilities to take advantage of the tax shield benefits, which is consistent with the view of Jam-e-Kausar (2012), Chang et. al. (2014), Wahab and Ramli (2014), Cevheroglu-Acar (2018). However, Chechet et al. (2013), Acaravci (2015), Windayu (2016), and Li and Islam (2019) argue that tangible fixed assets can negatively impact the financial decisions. Accordingly, when tangible fixed assets increase, the firms often restrict the use of liabilities to reduce the risk of bankruptcy due to the burden of liabilities. In emerging economies, short-term liabilities have accounted for a major proportion of total loans. Therefore, the firms in these economies tend to restrict the use of liabilities to invest in tangible fixed assets to limit the financial risks. Based on this basis, the author has hypothesized for this article as follows:

\section{$H_{3}$ : Tangibility (TANG) negatively affects financing decision (FD).}

\subsection{Impact of firm growth on financing decisions}

The firms with high growth rates often need large amounts of capital to invest. This amount of capital can be mobilized from equity, or loans. Raising equity can take a long time because the procedure for issuing shares is complicated, which is clearly shown in the emerging economies. Therefore, the firms with high growth rates often seek financing from loans. With the decision to use the liabilities, the firms can mobilize a large amount of capital in a short time, avoiding missing out on potential business opportunities, but facing high financial risks is unavoidable. The positive impact of firm growth on financial decisions is also found in Chang et al. (2014), Sutomo et al. (2019). Therefore, the hypothesis is given by the author as follows:

\section{$H_{4}$ : Firm growth (GROWTH) positively affects financing decision (FD).}

\subsection{Impact of firm size on a financing decision}

Large-sized firms are more likely to access capital from credit institutions than small firms. As a result, large firms often borrow more. In other words, firm size can positively impact financial decisions. This was also found in several empirical studies, such 
as Moosa and Li (2012), Shah and Jam-e-Kausar (2012), Chechet et al. (2013), Aggarwal and Singh (2014), Chang et al. (2014), Wahab and Ramli (2014), Vuran et al. (2017), Li and Islam (2019), Sutomo et al. (2019). In addition, there is still a small number of studies suggesting that large firms should still prefer to use equity (i.e. restricting liabilities), such as Acaravci (2015). Therefore, most previous studies have suggested that firm size has a positive impact on financial decisions. Therefore, the author proposes the hypothesis for this article as follows:

\section{$H_{5}$ : Firm size (SIZE) positively affects financing decision (FD).}

\section{Methodology}

The study data is collected from the financial statements of 110 manufacturing firms listed on Vietnam's stock market. Data was collected during 2011-2018. This article focuses on the determinants of financial decisions of manufacturing firms in Vietnam. To do this, the author will use the Generalized Method of Moment (GMM) to estimate the study model to ensure that the estimation results can control potential endogenous and overcome theregression hypotheses which are violated (Bui, 2020b, 2020c, 2020d; Doan, 2020a, 2020b; Doan \& Bui, 2020). Based on the results of previous studies, the author has measured financing decision (FD) through the ratio of total liabilities and total assets. The variables affecting financing decision (FD) are: profitability (ROA), liquidity (LIQ), tangible fixed assets (TANG), firm growth (GROWTH), firm size (SIZE). Therefore, the proposed study model has the following equation:

$\mathrm{FD}_{\text {it }}=\beta_{0}+\beta_{1} \mathrm{ROA}_{\mathrm{it}}+\beta_{2} \mathrm{LIQ}_{\mathrm{it}}+\beta_{3} \mathrm{TANG}_{\mathrm{it}}+\beta_{4} \mathrm{GROWTH}_{\mathrm{it}}+\beta_{5} \mathrm{SIZE}_{\mathrm{it}}+\varepsilon_{\mathrm{it}}$

Table 1

Summary of variables in the study model

\begin{tabular}{lcc}
\hline \multicolumn{1}{c}{ Variable name } & Code & Method of calculation \\
\hline Financing decision & Dependent variable \\
\hline Profitability (Return on Assets) & Total debt / Total assets \\
Liquidity & Independent variables \\
Tangibility & ROA & Profit after tax / Total assets \\
Firm growth & LIQ & Current assets / current liabilities \\
Firm size & TANG & Fixed assets / total assets \\
\hline
\end{tabular}

\section{Results}

First of all, the author analyzes the autocorrelation in the study model. This result is described in Table 2 below.

Table 2

Results of autocorrelation analysis in the study model

\begin{tabular}{lcccccc}
\hline & FD & ROA & LIQ & TANG & GROWTH & SIZE \\
\hline FD & 1.000 & & & & & \\
ROA & -0.488 & 1.000 & & & & \\
LIQ & -0.595 & 0.255 & 1.000 & 1.000 & 1.000 & 0.088 \\
TANG & -0.043 & -0.052 & -0.140 & 0.025 & 0.219 & 1.000 \\
GROWTH & 0.018 & 0.003 & -0.009 & -0.151 & & \\
SIZE & 0.220 & -0.127 & &
\end{tabular}

The results of autocorrelation analysis show that FD correlates negatively with ROA, LIQ, and TANG. Meanwhile, GROWTH and SIZE positively correlated with FD (Table 2).

Table 3

Test of study model

\begin{tabular}{|c|c|c|c|}
\hline $\begin{array}{c}\text { Multic } \\
\text { Variable }\end{array}$ & VIF & Modified Wald test & Wooldridge test \\
\hline ROA & 1.08 & \multirow{6}{*}{$\begin{array}{l}\text { chi2 }(110)=1.1 * 10^{5} \\
\text { Prob }>\text { chi2 }=0.000^{* * *}\end{array}$} & \multirow{6}{*}{$\begin{array}{l}\mathrm{F}(1,109)=44.745 \\
\text { Prob }>\mathrm{F}=0.000^{* * *}\end{array}$} \\
\hline LIQ & 1.10 & & \\
\hline TANG & 1.06 & & \\
\hline GROWTH & 1.01 & & \\
\hline SIZE & 1.08 & & \\
\hline \multicolumn{2}{|c|}{ Mean VIF $=1.07$} & & \\
\hline
\end{tabular}

Note: ${ }^{* * *}$ indicates significance at the $1 \%$ level.

Table 3 shows that the multicollinearity in the study model is considered to be not serious, because the mean VIF $<10$. However, the study model has theheteroscedasticity and autocorrelation with $1 \%$ significance level. Therefore, the estimation results based 
on the basic methods on tabular data are no longer reliable. To overcome this problem, the author will use the GMM method to estimate the study model to obtain the best results.

\section{Table 4}

Results of study model estimation

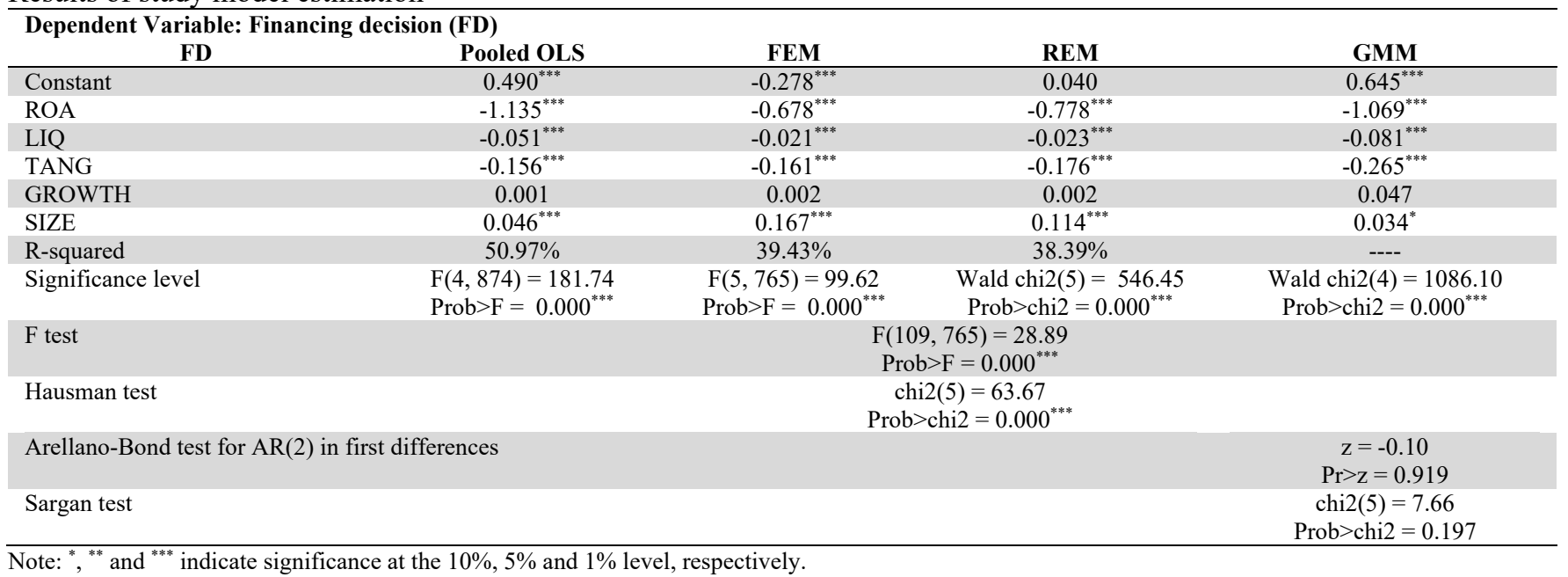

Table 4 shows that, in the basic methods, the Fixed effects model (FEM) analysis method is more suitable because F test and Hausman test are statistically significant at the 1\% significance level. However, the study model has heteroscedasticity and autocorrelation. Therefore, the author will use the results of estimating GMM study model to ensure the most optimal study results. Accordingly, the results of the study model estimation are significant at 1\%. And also, Sargan test and Arellano-Bond test for AR (2) in first differences are suitable. Therefore, the results of estimating the study model according to GMM method are suitable and usable. Therefore, FD is negatively affected by ROA $(\beta=-1.069)$, LIQ $(\beta=-0.081)$, TANG $(\beta=-0.265)$ with $1 \%$ significance level. And also, SIZE has a positive impact $(\beta=0.034)$ on FD with a $10 \%$ significance level. In this article, the author has not found a statistically significant impact of GROWTH on FD. Based on this basis, the results of estimating the study model have the following equation:

$$
\mathrm{FD}_{\mathrm{it}}=0.645-1.069 \mathrm{ROA}_{\mathrm{it}}-0.081 \mathrm{LIQ}_{\mathrm{it}}-0.265 \mathrm{TANG}_{\mathrm{it}}+0.034 \mathrm{SIZE}_{\mathrm{it}}+\varepsilon_{\mathrm{it}}
$$

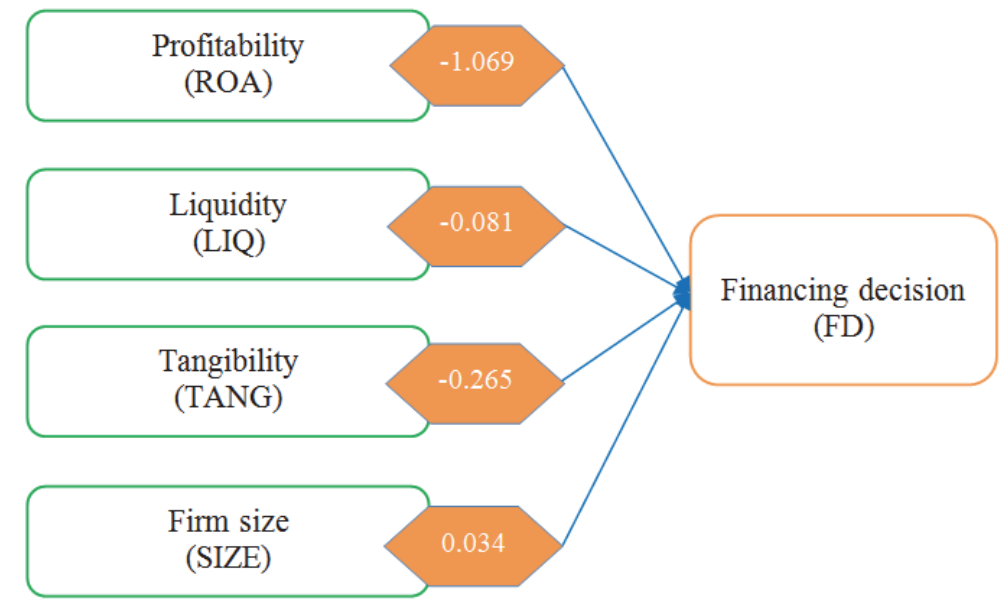

Table 5

Fig. 1. Study model results

Results of hypothesis testing

\begin{tabular}{rcc}
\hline & Hypothesis & Results \\
\hline $\mathrm{H}_{1}$ & Accepted & Accepted \\
$\mathrm{H}_{2}$ & Accepted & Rejected \\
$\mathrm{H}_{3}$ & $\mathrm{H}_{4}$ & Accepted \\
$\mathrm{H}_{5}$ & \\
\hline
\end{tabular}


- Impact of profitability (ROA) on financing decision (FD): The author has found the negative impact of ROA on FD. This shows that, when profits increase, the firms can choose to use retained earnings to reinvest, meaning to limit the use of liabilities. With the use of capital from retained earnings, the firms will easily raise capital in a short time, with low capital cost. Moreover, the firms also limit the risk of increased financial risks due to the use of loans. This result is also consistent with most previous studies: Shah and Jam-e-Kausar (2012), Chechet et al. (2013), Chang et al. (2014), Wahab and Ramli (2014), Acaravci (2015), Windayu (2016), Vuran et al. (2017), Cevheroglu-Acar (2018), Li and Islam (2019), Sutomo et al. (2019).

- Impact of liquidity (LIQ) to financing decision (FD): The study results show that LIQ has a negative impact on FD. This result is consistent with the previous views of Moosa and Li (2012), Wahab and Ramli (2014), Cevheroglu-Acar (2018). Accordingly, the firms with high liquidity are more active in paying short-term liabilities. On the other hand, with a large amount of working capital, these firms often restrict borrowing.

- Impact of tangibility (TANG) on financing decision (FD): The author has found the negative impact of TANG on FD. This impact is also found in the study of Chechet et al. (2013), Acaravci (2015), Windayu (2016), Li and Islam (2019). In Vietnam, short-term liabilities account for a major proportion of total loans. If the firms use this short-term loan to invest in tangible fixed assets, they will face many risks. Therefore, these firms often use equity to invest in tangible fixed assets.

- Impact of firm size (SIZE) on financing decision (FD): Study results show that SIZE has a positive impact on FD. This shows that large firms often borrow more. Because firms often have many favorable conditions when accessing loans. This result is also consistent with the previous views of Moosa and Li (2012), Shah and Jam-e-Kausar (2012), Chechet et al. (2013), Aggarwal and Singh (2014), Chang et al. (2014), Wahab and Ramli (2014), Vuran et al. (2017), Li and Islam (2019), Sutomo et al. (2019).

\section{Conclusion}

This article has achieved its objectives when determining the determinants of financial decisions of manufacturing firms in Vietnam. Accordingly, the financial decisions are negatively affected by profitability, liquidity, and tangibility. In addition, the author found the positive impacts of firm size on financial decisions. Based on the results of this study, firm managers will have a reliable basis for making reasonable financial decisions. Moreover, the results of this study are empirical evidence of manufacturing firms in an emerging economy. Therefore, the author's findings will be of reference value and important for other emerging economies in the world.

\section{References}

Acaravci, S.K. (2015). The determinants of capital structure: evidence from the Turkish manufacturing sector. International Journal of Economics and Financial, 5(1), 158-171.

Aggarwal, A., \& Singh, Y.P. (2014). Determinants of corporate capital structure: with special reference to home appliances industry in India. International Journal of Research in Computer Application and Management, 4(9), 87-91.

Bui, T.N. (2019a). The role of financial development in the Vietnam economy. WSEAS Transactions on Business and Economics, 16, 471-476.

Bui, T.N. (2019b). Inflation and stock index: evidence from Vietnam. Journal of Management Information and Decision Sciences, 22(4), 408-414.

Bui, T.N. (2020a). Stock holding decisions of foreign investors in emerging stock markets: A case study in Vietnam. Management Science Letters, 10(3), 625-630.

Bui, T.N. (2020b). How do financial leverage and supply chain finance influence firm performance? Evidence from construction sector. Uncertain Supply Chain Management, 8(2), 285-290.

Bui, T.N. (2020c). How does financial development affect the employment? Evidence from Asean countries. Journal of Management Information and Decision Sciences, 23(1), 1-6.

Bui, T.N. (2020d). Supply chain finance, financial development and profitability of real estate firms in Vietnam. Uncertain Supply Chain Management, 8(1), 37-42.

Doan, T.T.T. (2020a). Profitability of real estate firms: Evidence using GMM estimation. Management Science Letters, 10(2), 327-332.

Doan, T.T.T. (2020b). Financing decision and firm performance: Evidence from an emerging country. Management Science Letters, 10(4), 849-854

Doan, T.T.T., \& Bui, T.N. (2020). Nonlinear impact of supply chain finance on the performance of seafood firms: A case study from Vietnam. Uncertain Supply Chain Management, 8(2), 267-272.

Cevheroglu-Acar, M.G. (2018). Determinants of Capital Structure: Empirical Evidence from Turkey. Journal of Management and Sustainability, 8(1), 31-45. 
Chang, C., Chen, X., \& Liao, G. (2014). What are the reliably important determinants of capital structure in china?. PacificBasin Finance Journal, 30, 87-113.

Chechet, I.L., Garba, S.L., \& Odudu, A.S. (2013). Determinants of capital structure in the Nigerian chemical and paints sector. International Journal of Humanities and Social Science, 3(15), 247-263.

Cui, J., Jong, F.D., \& Ponds, E. (2011). Intergenerational risk sharing within funded pension schemes. Journal of Pension Economics and Finance, 10(1), 1-29.

Ha, V. (2020). Does bank capital affect profitability and risk in Vietnam?. Accounting, 6(3), 273-278.

Li, L., \& Islam, S.Z. (2019). Firm and industry specific determinants of capital structure: Evidence from the Australian market. International Review of Economics \& Finance, 59, 425-437.

Modigliani, F., \& Miller, M.H. (1958). The cost of capital, corporate finance and the theory of investment. American Economic Review, 48, 261-297.

Moosa, I., \& Li, L. (2012). Firm-specific factors as determinants of capital structure: Evidence from Indonesia. Review of Pacific Basin Financial Markets and Policies, 15(2), 1-17.

Pahuja, A., \& Sahi, A. (2015). Factors affecting capital structure decisions: Empirical evidence from selected Indian firms. International Journal of Marketing, Financial Services and Management Research, 3(3), 76-86.

Shah, S.Z.A., \& Jam-e-Kausar (2012). Determinants of capital structure of leasing companies in Pakistan. Applied Financial Economics, 22(22), 1841-1853.

Sutomo, S., Wahyudi, S., Pangestuti, I.R.D., \& Muharam, H. (2019). Determinants of financing decision: empirical evidence on manufacturing firms in Indonesia. Investment Management and Financial Innovations, 16(2), 159-170.

Vuran, B., Taş, N., \& Adiloğlu, B. (2017). Determining the Factors Affecting Capital Structure Decisions of Real Sector Companies Operating in ISE. International Journal of Economics and Finance, 9(8), 25-32.

Wahab, S.N.A., \& Ramli, N.A. (2014). The determinants of capital structure: an empirical investigation of Malaysian listed government linked companies. International Journal of Economics and Financial Issues, 4(4), 930-945.

Windayu, C.R. (2016). Factors Affecting the Capital Structure in Textile and Garment Listed in Indonesia Stock Exchange. IOSR Journal of Business and Management, 18(10), 83-88.

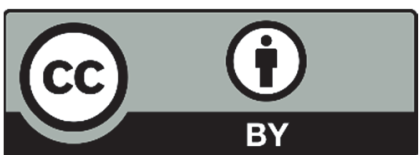

(C) 2020 by the authors; licensee Growing Science, Canada. This is an open access article distributed under the terms and conditions of the Creative Commons Attribution (CC-BY) license (http://creativecommons.org/licenses/by/4.0/). 